\title{
Nature and perpetual peace in Kant and Fichte's cosmopolitanism
}

Naturaleza y paz perpetua en el cosmopolitismo de Kant y Fichte

\section{EMILIANO ACOSTA}

Vrije Universiteit Brussel

Department of History, Archeology, Philosophy and Ethics

1050, Brussels (Bélgica)

emiliano.acosta@vub.be

Abstract: This is a comparative study of the concept of nature in Kant and Fichte's proposals for perpetual peace. I will argue that Kant and Fichte's ideas of perpetual peace present two very different ways of dealing with nature: whereas Kant's proposal consists of administrating the natural unsociable inclinations of human beings, departing from the assumption that the unsociable sociability of men is not only inherent to human nature but also the motor of the historical progress of humanity, Fichte, on the contrary, advocates for a total repression of these inclinations, departing from the postulate that the historical progress of humanity concerns exclusively the spiritual or intelligible dimension of human existence.

Keywords: Perpetual peace; cosmopolitanism; nature; providence.
Resumen: El presente artículo consiste en un estudio comparativo de la noción de naturaleza presente en las reflexiones de Kant y Fichte acerca de la paz perpetua. Se intentará mostrar que las ideas de Kant y Fichte acerca de la paz perpetua ofrecen dos modos distintos de tratar la naturaleza: mientras Kant propone, como medio para progresar hacia la paz perpetua, administrar la insociable sociabilidad del hombre, dado que, según sostiene, esta inclinación asocial y destructiva es inherente a la naturaleza humana, Fichte sugiere que la paz perpetua presupone, como medio para alcanzarla, la represión total de toda inclinación natural, entendiendo así que el progreso de la humanidad no concierne a la naturaleza sino al espíritu.

Palabras clave: Paz perpetua; cosmopolitismo; naturaleza; providencia. 
I what follows, I present a comparative study of Kant and Fichte's views on the role and function of nature in their conceptions of perpetual peace. ${ }^{1}$ I will mainly focus on Kant's essays "Idea for a Universal History with a Cosmopolitan Aim" and "Toward Perpetual Peace" and on Fichte's review of "Toward Perpetual Peace" and his book The Closed Commercial State. I will argue that Kant and Fichte's ideas of perpetual peace offer two very different ways of dealing with nature: whereas Kant's proposal consists of administrating the natural unsociable inclinations of human beings and departs from the assumption that the unsociable sociability of man is not only inherent to human nature but also the motor of the historical progress of humanity; Fichte, for his part, advocates for a total repression of these inclinations, departing from the hypotheses that the natural egoism of man can be corrected through an ascetic transformation of culture and that the historical progress of humanity concerns exclusively the spiritual or intelligible dimension of human existence on earth. Contrary to both the specialized literature on Kant, which considers the issue of nature related to cosmopolitanism as confusing or irrelevant, ${ }^{2}$ and the Fichte-schol-

1. Following abreviations are used in the footnotes: "IUH" for I. KANT, Idea for a Universal History with the Cosmopolitan Aim, transl. by A. Wood, in A. OKsEnBERG RORTY, J. SCHMIDT (eds.), Kant's Idea for a Universal History with a Cosmopolitan Aim. A critical Guide (CUP, Cambridge, 2009) 9-23; TPP for I. KANT, Toward Perpetual Peace: A Philosophical Sketch, transl. by D. Colclausure, in P. KLEINGELD (ed.), Toward Perpetual Peace and Other Writings on Politics, Peace and History (Yale University Press, New Heaven/London, 2006) 67-109; "IaG" for "Idee zu einer allgemeinen Geschichte in weltbürgerlicher Absicht", "ZeF" for "Zum ewigen Frieden: Ein philosophischer Entwurf", "RezPP" for Fichte's review of Kant's Perpetual Peace and "GHS" for Fichte's The Closed Commercial State. The work of Kant is cited from the Akademie Ausgabe (from now on AA vol.: pp.): I. KANT, Gesammelte Schriften, vols. 1-22 ed. by the Preussische Akademie der Wissenschaften, vol. 23 ed. by the Deutsche Akademie der Wissenschaften zu Berlin, vol. 24ff. ed. by the Akademie der Wissenschaften zu Göttingen (DeGruyter, Berlin, 1900ff.). Fichte's works are cited according to J. G. FICHTE, Gesamtausgabe der Bayerischen Akademie der Wissenschaften (from now on GA series number/vol., pp.). E. FuCHS, R. Lauth, H. Jacobs, H. GliwitzKy (eds.) (Frommann-Holzboog, StuttgartBad Cannstatt, 1964-2012).

2. See, for instance, Ypi's short but very clear overview of the different approachings to nature in the existing literature on Kant's cosmopolitanism in L. YPI, Natura Daedala Rerum? On the Justification of Historical Progress in Kant's Guarantee of Perpetual Peace, "Kantian Review" 14-2 (2010) 118-119. 
arship, in which this issue still remains unattended, ${ }^{3}$ I will argue that these different views on nature are essential for understanding both philosophers' conceptions of the political and economic situation needed for progressing towards the dreamed perpetual peace, since the way in which Kant and Fichte conceive nature, when dealing with cosmopolitanism and philosophy of history, conditions the way in which they describe the most perfect global community. Whereas Kant considers it as a strongly economic and political interdependence among states, Fichte thinks of perpetual peace as the result of an almost total cessation of international relations among statessince Fichte's radical protectionism allows, however, scientific and cultural international exchange.

I begin with an analysis of Kant's concept of nature, legal cosmopolitanism, war and international trade from a cosmopolitan perspective and with a cosmopolitan aim, namely in their relation to his idea of perpetual peace (1), then I examine how these concepts are conceived and related to each other in Fichte's mentioned works (2). In the last part (3), I offer as a conclusion some remarks on the conceptual differences between both philosophers.

\section{KANT: NATURE AS GUARANTEE AND FACILITATOR OF HUMAN PROGRESS TOWARDS PERPETUAL PEACE}

Certainly, one of the more intriguing things of Kant's legal and political cosmopolitanism is the conception of nature that accompanies his cosmopolitan proposal. Both, in "Idea for a Universal History with a Cosmopolitan Aim" of 1784 and the 1795 essay "Toward Perpetual Peace", Kant does not hesitate in identifying nature with

3. See as an example of the indifference towards Fichte's concept of nature in studies on his political writings I. NAKHIMOvsKY, The Closed Commercial State (Princeton University Press, Princeton, 2011). See for an overview of studies on Fichte's concept of nature in general Traub's detailed and well-documented research repport on Fichte's concept of nature in H. TRAub, Fichtes Begriff der Natur. Rezeptiongeschichte im Wandel - Ein Forschungsbericht, in H. GIRNDT (ed.), "Natur" in der Transzendentalphilosophie. Eine Tagung zum Gedenken an Reinhard Lauth (Duncker \& Humblot, Berlin, 2015) 77-134. 
providence. ${ }^{4}$ This identification, which, paraphrasing Spinoza, can be formulated as providentia sive natura, represents the main (regulative) idea of his attempts at sketching, in both mentioned writings, a philosophy of history. According to Kant, the history of humanity consists of the accomplishment of a plan that nature has designed for the human species. ${ }^{5}$ Other ideas and concepts that we find in these essays such as the teleological character of the existence of humankind on earth, the need of a republican form of government as well as of an international and cosmopolitan legal order for assuring the cultural and moral progress of humanity and even the ideal of perpetual peace and the preliminary and definitive articles for a peace treaty are, therefore, subsidiary to this very peculiar conception of nature. As I argued elsewhere, ${ }^{6}$ the argumentative core of Kant's idea of perpetual peace and legal cosmopolitanism resides in that big narrative about the historical destination of humanity. In this regard, it must not surprise us the fact that when Kant has to shortly define his 1784 article, he calls it, not without reason, a "justification of nature."

It is very well-known that in his article "Idea for a Universal History with a Cosmopolitan Aim”, Kant presents for the first time to the German public his concept of legal cosmopolitanism. ${ }^{8}$ It is commonly assumed that the topic of legal cosmopolitanism represents the core of this essay. This is, to my view, the reason why Kant's 1784 article on history has also commonly been considered as nothing but a first attempt or a draft of the more elaborated theory of legal cosmopolitanism, which he presented some years later in his essay "Toward Perpetual Peace." However, a close reading of Kant's 1784 article let us see that, despite of its relevance, legal cos-

4. IaG, AA 08:30; ZeF, AA 08:361.

5. IaG, AA 08:27.

6. E. Acosta and G. VAn DE VIjVER, While reading Kant's Perpetual Peace, in D. PRAET (ed.), Philosophy of war and peace (VUBPress, Brussel, 2017) 131-144.

7. IUH 22 (IaG, AA 08:30).

8. IUH 16-17 (IaG, AA 08:24).

9. See P. Kleingeld, Kant's changing Cosmopolitanism, in A. Oksenberg Rorty, J. SCHMidT (eds.), Kant's Idea for a Universal History with a Cosmopolitan Aim. A Critical Guide (Cambridge University Press, Cambridge, 2009) 181-182. 
mopolitanism is not its central issue, but a concept, as I said above, subordinated to the real main topic of this article, namely, the idea of a plan of nature guiding human history.

If we, for instance, analyze the introduction and the nine propositions that make up this article, we will see that Kant discusses the possibility and benefits of legal cosmopolitanism only in two of the nine propositions, namely the seventh and the eighth proposition. Furthermore, at the beginning as well as at the end of the eighth proposition Kant makes his point perfectly clear about the, certainly, significant, but still subordinated, systematic place of legal cosmopolitanism in his proposal for a universal history with a cosmopolitan aim. The eighth proposition reads as follows:

One can regard the history of the human species in the large as the completion of a hidden plan of nature to bring about an inwardly and, to this end, also an externally perfect state constitution, as the only condition in which it can fully develop all its predispositions in humanity. ${ }^{10}$

And at the end of the eighth proposition we read:

Although this state body [sc. a federation of nations] for now stands before us only in the form of a very rough project, nevertheless already a feeling begins to stir in all members, each of which has an interest in the preservation of the whole; and this gives hope that after many transforming revolutions, in the end that which nature has as its aim will finally come about - a universal cosmopolitan condition, as the womb in which all original predispositions of the human species will be developed. ${ }^{11}$

In both quotes, legal cosmopolitanism does not appear as a goal in itself but rather as a condition or requirement for achieving the real 
goal of humanity, the goal that nature has imposed to the humankind: the total development of all its original predispositions.

Moreover, as we can read in the above-quoted formulation of the eighth proposition, the argumentative connection between legal cosmopolitanism and the full development of human potentialities is actually mediated through the concept of a perfect nation-state constitution. Therefore, legal cosmopolitanism's contribution to the progress of humanity essentially consists of guaranteeing the principal condition for this progress, namely the stability of the state of law in each country, which is required for peaceful interactions among citizens and, therefore, for the cultivation of the natural dispositions of the human species. In this regard, Kant considers legal cosmopolitanism as a condition of second degree, namely: a condition for the first condition (the establishment of a rational national state constitution).

According to Kant, a rationally designed and established domestic legal order that coercively organizes and disciplines the wellknown "unsociable sociability"12 is precisely that which the human species needs in order to achieve cultural progress. Only in this kind of politically structured civil society-that Kant compares with a "precinct [Gehege]"-human self-destructive antagonism brings forth its "best effect." 13 Nevertheless, the security that governments provide to citizens, is limited, since it only protects each individual freedom from the danger represented by the unsocial inclinations of the rest of civil society. As Kant observes, besides the menace that each citizen represents for the others, there are two other threats to citizen rights and consequently also to political stability and rule of law in a nation-state, namely: misuse or abuse of the power by the government ${ }^{14}$ and, naturally, war. ${ }^{15}$

Kant's proposal of legal cosmopolitanism acts as an antidote against such abuses. On the one hand, international agreements and legislation regulating the relations among states and foreign citizens

12. IUH 13 (IaG, AA 08:20).

13. IUH 15 (IaG, AA 08:22), see also IUH 18 (AA 08:25).

14. IUH 15 (IaG, AA 08:23).

15. IUH 16 (IaG, AA 08:24). 
will facilitate and promote world trade, the growth and intensification of international commerce will function as an impediment for any possible infringement of civil freedom by national governments, since any violation of civil rights will necessarily result in a disadvantage for the economy of the respective state. ${ }^{16}$ On the other hand, not only the mentioned intensification of international trade network will condition any future declaration of war, ${ }^{17}$ but also the effective reality of legal cosmopolitanism, namely the existence of an international institution with coercive power for regulating the relations among states, will guarantee that the nation that dares to attack one of the members of the federation of nations, will be punished by the other members. ${ }^{18}$

Accordingly, legal cosmopolitanism is not a goal in itself, but it rather appears within the argumentative structure of Kant's 1784 article on universal history as a concept subordinated to a set of presuppositions and propositions that Kant elaborates in order to show that human existence on earth has a meaning as well as a goal, namely the development of "all original predispositions of the human species."19 In other words: Kant introduces the concept of legal cosmopolitanism exclusively as an answer to the question about the concrete actions that humanity has to take in order to achieve its own goal within the, as Kant calls it, "hidden plan of nature." ${ }^{20}$

As we can read in Kant's 1784 article, the concept of legal cosmopolitanism is directly related to a particular view of nature, human nature and its historicity. The main argument defending his proposal for the establishment of a federation of Nation-States is that without such a federation, firstly, the human species could not accomplish the goal that nature has imposed to humanity, secondly, there would be, consequently, germs and predispositions in nature, more specifically in the human species, that would not completely

16. IUH 19-20 (IaG, AA 08:27).

17. IUH 20 (IaG, AA08:28).

18. IUH 18 (IaG, AA 08:26).

19. IUH 21 ( IaG, AA 08:28).

20. IUH 19 (IaG, AA 08:27). 
develop, and hence, thirdly, we should conclude that nature would have produced something purposeless and absurd, what actually contradicts "the teleological doctrine of nature." ${ }^{21}$ So, without the presupposition of the "hidden plan of nature" the claim about the need and benefits of an international legal order loses the rhetoric power that Kant certainly wanted to confer to his legal cosmopolitanism in order to convince and mobilize politicians and world leaders towards an enlightened and cosmopolitan way of understanding and practicing politics. ${ }^{22}$

In 1795 , Kant presents the same hierarchical chain of conditionality. In "Toward Perpetual Peace" Kant distinguishes three levels of law: ius civitatis, ius gentium and ius cosmopoliticum..$^{23}$ Each level of law functions as a guarantee to the former. Kant does not consider them as goals in themselves, but as the legal instruments needed for constructing the best possible political scenario for both the total development of the human potentialities and the institutional progress toward perpetual peace. According to Kant, these three law-levels are necessary only "in relation to the idea of perpetual peace". ${ }^{24}$ Like in 1784, Kant affirms in 1795 that the need of a republican form of government as well as a federation of nations and the establishment of an international codex for protection of human rights is a requirement based in the natural social unsociability of man, a result of nature's intervention in human history. ${ }^{25}$ That Kant, in 1795, did not change his mind about the argumentative dependence of legal cosmopolitanism to his idea of nature as providence becomes still clearer in the "First Supplement". Kant not only affirms again that nature and providence are one and the same thing and provides for a more detailed analysis of the concept of providence, ${ }^{26}$ but also restates his 1784 thesis that human actions, and consequently the establishment of domestic and international

21. IUH 11 (IaG, AA 08:18).

22. IUH 19-23 (IaG, AA 08: 27-31). See also ZeF, AA 08: 360, 361n. and 386.

23. ZeF, AA 08:349n.

24. Ibidem. See also ZeF, AA 08:365.

25. ZeF, AA 08: 352, 355, 360-361.

26. ZeF, AA 08:361n. 
institutions and regulations, are following, although without knowing it, a plan designed by the wisdom of nature. ${ }^{27}$ In this regard, it does not seem wrong to affirm that Kant's intervention in the 18th-century debate on the problem of establishing a perfect civil constitution and on global justice goes beyond the limits of philosophy of law and political economy and situates in the domains of anthropology and philosophy of history.

Kant's idea of a hidden plan of nature entails a redefinition of both nature and man. Nature, as I said above, is identified with providence. This identification implies not only that nature is guiding human history but also that it wisely does so, since it knows what is good for humankind. ${ }^{28}$ Kant's history of humanity does neither begin with nature's revelation of this wisdom to man nor depends on a transference of knowledge, since within Kant's big narrative about historical human progress, the reverse of nature's wisdom is human ignorance:

Individual human beings and even whole nations think little about the fact [i.e. that there is a uniform uninterrupted course of history], since while each pursues its own aim in its own way and one often contrary to another, they are proceeding unnoticed, as by a guiding thread, according to an aim of nature, which is unknown to them, and are laboring at its promotion, although even if it were to become known to them it would matter little to them. ${ }^{29}$

This description of human ignorance of the real aim of human actions at the very beginning of Kant's 1784 article provides already a first mention, though not totally explicit, of the "antagonism in society", namely the "social unsociability of human beings", which Kant presents and analyzes in the fourth proposition of this essay. ${ }^{30}$ Kant never changed his mind about this topic in his later works: not only

27. ZeF, AA 08:361.

28. IaG, AA 08:21; ZeF, AA 08:367-368.

29. IUH 10 (IaG, AA 08:17), see also ZeF, AA 08:365.

30. IUH 13 (IaG, AA 08:20). 
it appears again in $1795,{ }^{31}$ but also at the end of his 1798 Antbropology. ${ }^{32}$ As A. Wood, the English translator of Kant's 1784 article, observes, we can read behind Kant's formulation of human antagonism the statement of Michel de Montaigne that "there is nothing more unsociable than Man, and nothing more sociable: unsociable by his vice, sociable by his nature." ${ }^{33}$ Despite of the value that this possible historiographical connection may have, I think that such a comparison actually does not explain anything of Kant's social unsociability, but, on the contrary, functions as an impediment for understanding the originality of Kant's view on the human nature.

According to Kant, the social unsociability does not reflect a conflict between vice and nature. Moreover, there is for him no duality in human nature, when it is considered with a cosmopolitan aim. ${ }^{34}$ Man's inclination to become socialized and his propensity to isolate himself by means either of resisting the will of the others or neglecting their freedom and dignity, are both egoistic inclinations: nothing but two sides of the same "self-interest" 35 that guides human actions. Man's instinct to enter in a society does not obey, according to Kant, to a kind of natural wisdom or moral sense that individuals have. Furthermore, morality is rather an historical effect of social antagonism. ${ }^{36}$ Besides, contrary to Montaigne's moralizing platitude, Kant's concept of social unsociability excuses individuals from any kind of guilt or punishment, since according to Kant, individuals actually do not know what they are doing nor pursuing through their deeds, so they cannot be imputable at all. Moreover, the genus proximum in Kant's definition of the social antagonism in the fourth proposition puts it very clearly: social unsociability is a means of nature not of man. Last but not least, Kant does not complain about these egoistic inclinations, precisely on the contrary, he

31. ZeF, AA 08:360, 368, see also AA 12:10 (Kant's letter to Schiller dated on 30 March 1795).

32. ZeF, AA 08:368; Anthr, AA 09:330-333.

33. M. E. De Montaigne, The Complete Essays, transl. by M. A. Screech (Penguin Books, London, 1991) 267, quoted from IUH 13 n. a.

34. IUH 13 (IaG, AA 08:20).

35. TPP 92 (ZeF, AA 08:368).

36. IUH 14 (IaG, AA 08:21); ZeF AA 08:366. 
praises them by considering the motor of history, rather than an evil, and, consequently, the cause of "all culture and art that adorn humanity, and [of] the most beautiful social order." ${ }^{37}$

Kant's praise of Nature is more than a rhetorical gesture, for it expresses his conviction that without this antagonism humanity would not have any historical progress at all:

Without these qualities of unsociability from which the resistance arises, which are not amiable in themselves, qualities that each of us must necessarily encounter in his selfish pretensions, all talents would, in an arcadian pastoral life of perfect concord, contentment and mutual love, remain eternally hidden in their germs; human beings, as good-natured as the sheep they tended, would give their existence hardly any greater worth than that of their domesticated beasts; they would not fill the void in creation in regard to their end as rational nature. ${ }^{38}$

Since this antagonism is a means of nature and not of man, the fact that without conflict there would neither be progress nor history is not due to man's freedom but to nature's coercion. The human being, according to Kant, "wills concord; but nature knows better what is good for his species: it wills discord." ${ }^{39}$ In 1795, Kant expresses the same idea in the following terms:

When I say that nature wills that this or that ought to happen, I do not mean that she imposes a duty upon us to act thus (for this can only be done by practical reason acting free of compulsion), but rather that she does it herself, regardless of whether we will it so or not (fata volentem ducunt, nolentem trabunt). ${ }^{40}$

Individual freedom, according to Kant, is irrelevant for understanding the history of humanity, since for the historical progress of hu-

37. IUH 15 (IaG, AA 08:22). See also IaG, AA 08:21 and ZeF, AA 08:366.

38. IUH 14 (IaG, AA 08:21).

39. Ibidem.

40. TPP 90 (ZeF, AA 08:365). 
manity toward perpetual peace it is not necessary that individuals know nor will what they actually are accomplishing for human progress. The desires, demands, goals, dreams, welfare and happiness of individuals have no relevance at all in the plan nature has designed, ${ }^{41}$ since, as we can read at the beginning of the second proposition of Kant's 1784 article, the subject of history is actually the species, humanity. "The role of the human being", Kant must confess, "is thus very artificial." ${ }^{43}$

Humanity, as the very subject of history, progresses, according to Kant, in a dialectical way. It does not only transit the negativity of amorality (war and oppression, for instance) in order to make morality possible and then real, ${ }^{44}$ but it also needs to go through the negativity of conflicts (state of nature, intrastate and international wars, economic competition among states) in order to reach the crisis needed (a political revolution, a change of the national or international economic paradigm) for advancing to the next step in this progress toward perpetual peace. Kant's conception of war in relation to the idea of perpetual peace illustrates the dynamics of history progress:

All wars are therefore only so many attempts (not, to be sure, in the aims of human beings, buy yet in the aim of nature) to bring about new relationships between states, and through destruction or at least dismemberment of all of them to form new bodies, which, however, once again cannot preserve themselves either in themselves or next to another and hence must suffer new, similar revolutions until finally, partly through the best possible agreement of their civil constitution internally, partly through a common agreement and legislation externally, a condition [Zustand] is set up, which, resembling a civil commonwealth, can preserve itself like an automaton. ${ }^{45}$

41. IUH 11-12/AA 08:18-20.

42. IaG, AA 08:18.

43. IUH 16 n. (IaG, AA 08:23n.).

44. See, for instance, IaG, AA 08:21 and ZeF, AA 08:366.

45. IUH 17 (IaG, AA 08:24-25), see also the same dialectic dynamics in Kant's 
In doing so, humanity is following the laws of nature mechanism, more specifically of the antagonism inherent to human nature. In this regard, the establishment of a federation of states and the promotion and the growth of international trade must not be merely understood as Kant's view on politics and economy, but rather as new, higher and more civilized forms of the original social unsociability. Given the fact that the antagonism is inherent to human nature, this antagonism cannot disappear, since without social unsociability there would not be human race as such on earth, but merely one more species of domesticated beasts. Hence, each new form of antagonism does not cancel the antagonism, but gives to the social unsociability a more complex structure that as such enables a broader and safer space for exerting freedom by means of reciprocally restricting the original "brute freedom" of human beings. ${ }^{46}$ This restriction occurs in all levels of human historicity and essentially consists of the creation of more complex interdependence relationships among the elements of each dimension of human life. Progress is achieved, for instance, through the restrictions to individual absolute freedom by means of civil laws within the state. These restrictions transform the individual to a citizen, which is a more complex determination of man and implies that each act of the individual depends on the acts of the others. By becoming a member of a federation of states, a nation-state restricts its own brute freedom and conditions its own actions and the actions of the other states at the same time within the legal framework of international law and agreements. The restriction in all cases is horizontal and vertical: horizontal in regard to the other members of the respective totality (civil society, the international community), vertical in regard to the law and agreements that regulate these totalities.

The impossibility of totally repressing human antagonism is based on Kant's idea that this antagonism is the motor of historical progress of humanity. Without a certain level of conflict there

formulation of nature's arrangements for guaranteeing progress toward perpetual peace in ZeF, AA 08:363.

46. IUH 17 (IaG AA 08:24). 
would not be any progress. For instance, in the most satisfactory situation of peace, Kant observes, danger must not be totally neutralized, but it must remain latent, because otherwise "the powers of humanity" would "fall asleep." 47

In Kant's description of human progress toward more and more complex structures and dynamics of social unsociality international trade is presented as the highest form of reciprocal restriction of freedom and interdependence. ${ }^{48}$ The spirit of trade makes certainly war impossible, but far from meaning the end of all conflicts, the spirit of trade is nothing but a more sophisticated and efficient form of social antagonism. Kant's apology of "the spirit of trade" and the "power of money" is, therefore, not an economic statement, but an encouraging claim about human destination, based on the acceptation that human antagonism and egoistic inclinations are not only essential to our nature, but also more primordial than morality. This is the reason why Kant's proposal for a political praxis toward perpetual does not consist of neglecting or condemning the social unsociability, but rather of elaborating a strategy for administrating this antagonism as efficiently as possible.

\section{FICHTE: REPRESSING NATURE AS THE ONLY EFFECTIVE}

MEANS TOWARDS PERPETUAL PEACE

In 1796, Fichte writes a review of Kant's "Toward Perpetual Peace" for Niethammer's "Philosophical Journal of a Society of German Scholars". Fichte's review almost literally recaps the content of the preliminary and the definitive articles and of the first supplement concerning the guarantee of perpetual peace. Since the review is on the first edition of Kant's essay, there is no mention of the second supplement, which is an addition of the second edition of this essay in 1796. About the two sections of the appendix on the relationship between morality and politics with respect to perpetual peace Fichte 
merely says that it contains some "truths accurately said." ${ }^{49}$ Only concerning two points of Kant's 1795 essay Fichte thinks it necessary to offer his own view: the separation of powers in a republic ${ }^{50}$ and the regulative idea of nature's wisdom guiding and administrating the egoistic inclinations of the individuals in order to progress towards perpetual peace.

Although Fichte does not say it explicitly, his own view on these issues expresses actually a criticism against Kant. ${ }^{51}$ The analysis of Fichte's first criticism, which entails Fichte's proposal of the ephorate, an institution that must control the executive power, falls outside of the scope of the present analysis. The second one, on the contrary, is relevant for the present paper, since it illustrates the essential divergence between Kant and Fichte concerning the role of nature, and consequently of the social unsociability as well, in the historical progress toward perpetual peace.

Unlike Kant, Fichte is skeptical about the alleged efficiency of what I have called the Kantian formula providentia sive natura. Kant's "Perpetual Peace" has not convinced Fichte that self-interest and the spirit of trade really serve for perpetual peace or, better, that they necessarily lead humanity to its final goal. Fichte suggests that self-interest left to itself does not produce a situation favorable for the establishment of a republican rule of law nor of peaceful international relations among the states.

It sounds obvious, Fichte observes, that men should always choose for a national constitution according with reasonable laws, since such a political order guarantees that all citizens can pursue their own egoistic aims by means of reciprocal restriction of their original freedom. However, Fichte adds, they do not act as expected: they support and strengthen through their deeds the existent unjust situation. Fichte must conclude that the only way

49. RezPP, GA I/3, 228.

50. RezPP, GA I/3, 225-226.

51. In the third section of the Introduction to his Foundations of Natural Law according the Principles of the Doctrine of Science, Fichte offers again a commentary on Kant's Perpetual Peace. This time, however, he only concentrates on the first of his criticisms against Kant, namely on the necessity of the ephorate (GA I/3, 326-328). 
of explaining this social behavior against social, political and economic justice and equality is by presupposing that "the advantages of disorder must be stronger than the advantages of order." ${ }^{52}$ Not only the ones who win with disorder and inequality, actively and consciously sustain such an unjust political situation, but also the others, who suffer the negative consequences of this system, do the same, since, according to Fichte, they hope that one day they also will enjoy these advantages, which, as all actors involved in this political drama know, are based on legal disorder, economic inequality and social and political oppression. The Kantian unsocial sociability does not seem, in Fichte's view, to open the way for humanity to global justice and equality.

Fichte's criticism goes directly against Kant's thesis that the antagonist mechanism of nature constantly and unavoidably generates crises that results in higher (more civilized) forms of unsocial sociability. Against this antagonism, the human being, Kant suggests, cannot do anything but, following the example of wise nature, trying to administrate it by creating new restrictions and, consequently, new interdependence links between citizens and states. In Kant's philosophy of history, progress toward perpetual is guaranteed by the impossibility of stopping the antagonism, which is essentially the motor of human historical progress. Fichte objects the Kantian dialectics in history, since he does not agree with Kant in the assumption that justice and equality historically are a product of nature, namely an outcome of the egoistic inclinations of the individuals and the states. Moreover, Fichte suggest that reality provides enough evidence that a certain intensity of oppression-a level of oppression that let everyone hope that he or she one day will be at the side of the winners of the unjust system-makes any kind of revolution impossible, since individuals seem to be satisfied in such a situation. Hence, they would not undertake any action-neither forced by nature nor inspired by moral sentiments-for changing the political and economic paradigm. ${ }^{53}$

52. RezPP, GA I/3, 227.

53. RezPP, GA I/3, 227-228. 
Fichte's criticism goes, however, even further: it does not only concern Kant's diagnosis and prognosis on human historical progress toward perpetual peace, but also the proposal for a rational intervention in history. Fichte suggests that the real solution to social, political and economic injustice does not consist of strengthening conflict and competitiveness in order to provoke political and economic revolutions, but in cancelling its very source, namely: nature as it is expressed in the Kantian unsocial sociability. ${ }^{54}$ Hence, Fichte's solution adopts the form of a set of ascetic practices towards self-control and/or domination of the source of evil in human nature. Montaigne's duality in man that Kant objected, is now essential to the Fichtean account on the progress toward perpetual peace. Fichte's argument is very simple: a domestic rule of law as well as an international legal order according to the principles of reason can only be achieved, if citizens and political leaders control their supreme vice, namely that "obsession for robbery [Raubsucbt]" that characterizes human nature ${ }^{55}$ and is the real cause of war.

According to Fichte, nature in man refers to that side of human duality that has to be neutralized. The body of the rational being, Fichte observes, is also a manifestation of that "Not-I", which the $\mathrm{I}$ is destined to totally conquer or even destroy. ${ }^{56}$ Fichte defines the goal of humanity in history as the "common cultivation of the pure human being." ${ }^{57}$ For achieving this goal there are according to Fichte three steps, which man has to accomplish: firstly, the creation of a pure moral and religious community, secondly the establishment of an absolute state of law on domestic and international levels, and, thirdly, the total dominance of nature under the authority of rational will. ${ }^{5}$ For Fichte, nature has always the negative connotation of being an impediment for human progress. The only way

54. In this regard, Nakhimovsky's claim that "Fichte's new approach to the problem of perpetual peace was based on the same theory of unsocial sociability as Kant's" neglects the profund divergences between both philosophers (I. NAKHIMOVSKY, op. cit., 47).

55. RezPP, GA I/3, 228.

56. GA I/3, 28-30 (Über die Bestimmung des Gelebrten, 1794).

57. GA I/8, 431 (Philosophy of Freemasonry. Letters to Konstant, 1802).

58. GA I/8, 440 (Philosophy of Freemasonry. Letters to Konstant, 1802). 
for integrating nature in human progress consists of considering it as the material for human action. Nature is that negativity without which the ceaseless striving of I and the absolute character of the imperative of practical reason could not be explained. ${ }^{59}$ So, Fichte cannot follow Kant in both ascribing wisdom to nature and identifying this sagacious nature with providence. Nevertheless, there is, according to Fichte, certainly a plan for humanity and this plan has been designed by a non-human intelligence, but whereas Kant calls this intelligence nature, Fichte calls it God, a name that for Fichte exclusively means the personification of the moral law. ${ }^{60}$

In the Fichtean account, nature, left to itself, only produces inequality: the differences of classes are a product of the individual natural capacities of human beings and these differences can only, and ought to, be remedied by freedom. ${ }^{61}$ Nature, Fichte affirms, has nothing to do with human history, since progress is a process that takes exclusively place in the spiritual element of human duality. Neither nature as such nor nature in man progresses, only the spirit progresses and progress is for Fichte only moral progress. ${ }^{62}$ Nature, in Fichte's view, is not anymore involved in any decision making concerning the destination of humanity.

In this new conceptual context, the will and the freedom of both the states and their citizens recovers the relevance that Kant's philosophy of history systematically neglected. The aim of the state (not of nature), according to Fichte, is to bring the citizens to a consciously deliberated renounce to the natural inclination of possessing everything. ${ }^{63}$ Hence, the progress of humanity towards national and global justice needs that citizens know what kind of goal they have to pursue. Hence, morality is for Fichte not a result of an amoral or immoral mechanism of historical progress, but it is situated at the very beginning of his conception of human progress. Unlike

59. GA I/2, 396 n. (Foundations of the Entire Science of Knowledge, 1794/95).

60. GA I/5 247 (On the Basis of our Belief in a Divine Governance of the World, 1798).

61. GA I/3, 42-50 (On the Destination of Scholars, 1794).

62. GA II/9, 145 (Manuscript of Fichte's 1805 Logic course at the University of Erlangen).

63. RezPP, GA I/3, 228. 
Kant, Fichte suggests that individuals' ignorance must necessarily be attacked, since without the knowledge about the destination of humanity, there is no human progress in history. Despite the similarities between Kant and Fichte's accounts on morality, both philosophers differ in their view on morality's extension of validity. Whereas Kant excludes the primacy of practical reason from his philosophy of history towards perpetual peace, ${ }^{64}$ Fichte's concept of human progress does not make any concession to any benefit that could spring forth from amoral or immoral human acts.

Kant and Fichte's views on war in relation to perpetual peace crystal clearly illustrate this disagreement. Both accept the unavoidability of war, but whereas Kant reinforces its necessity by giving it a positive function in human progress, Fichte considers war in itself as something accidental that actually should not happen. Moreover, since for Fichte there is no nature acting as providence, individuals and states are totally responsible of their acts. This is the reason, I would like to suggest, why Fichte has some complications in justifying that kind of war that is required in his protectionist theory for achieving the closing of the commercial state: military occupation as a means of the state in order to definitively establish its own borders before it proceeds to the closing of all its international commercial relations. ${ }^{65}$ Unlike Kant, for whom the aims of the states that wage war, are not relevant for cosmopolitan history, since ignorance is compensated by nature's wisdom, Fichte can only tolerate war, if it is deliberately waged in order to bring humanity closer to a situation of perpetual peace, namely if it attempts at putting an end to the "robbery obsession" $" 66$ on the level of international relations.

Fichte's proposal of collective renounce to egoistic inclinations can be achieved in civil society, when a nation has reached an "equilibrium of possessions", namely: an economic situation that everyone, the lower and the higher classes, can tolerate. This equilibrium can only come about through the deliberate and active intervention

64. See G. Cavallar, Cosmopolitanisms in Kant's philosophy, "Ethics \& Global Politics" 5/2 (2012) 96-97 and 106.

65. GHS, GA I/7, 134-135.

66. RezPP, GA I/3, 228. 
of the rational being in history. According to Fichte, inequality and injustice must be attacked by means of global increasing of production of goods, increasing of population and (re-)distribution of wealth. Once this situation of economic equality is established on national and international levels, Fichte concludes, there will be no need for international trade nor slavery. ${ }^{67}$ In the Kantian account, free world trade or free market economy is crucial for the development of the real conditions of possibility for legal cosmopolitanism. Kant understands free world trade as the highest and more efficient manifestation of the antagonism in relation to perpetual peace, since it makes war almost impossible and compels the states to establish more rational political institutions as well as to protect the freedom of their citizens. ${ }^{68}$ According to Fichte, perpetual peace, which is "the only rightful relation among States," ${ }^{\prime 9}$ can be reached, on the contrary, only if we actually proceed in the opposite way, namely: obstructing and impeding free market. This is the conclusion of his protectionist treatise on Political Economy The Closed Commercial State ${ }^{70}$ the principles of which Fichte already sketched in his review of the Kantian 1795 essay.

Concerning international trade in relation to perpetual peace, the differences between Kant and Fichte are still deeper. In his The Closed Commercial State Fichte offers a draft of a history of trade, in which international trade, contrary to Kant's view, is not presented as the future but as the past of human history. Progress is not free trade, but protectionism, Fichte affirms. Fichte argues that the political development of Europe into a diversity of nation-states has not yet been accompanied by a similar economic progress consisting of the creation of a diversity of closed commercial states. Like the "One Nation" that Christian Europe incarnated, free market economy is for Fichte a thing of the past, something that has been adopted without testing it $^{71}$ and accepted only because of tradition

67. Ibidem.

68. IaG, AA 08:27, see also ZeF, AA 08:367.

69. GA I/4, 162 (Foundations of Natural Law, 1796/97).

70. GHS, GA I/7, 119, 138 and 141.

71. GHS, GA I/7, 95. 
and conventions. Defending free international trade is for Fichte a dogmatic view of economy that contradicts the spirit of the Enlightenment. Hence, the economic system in Europe must develop in the same direction of political development, namely it must follow the development of State and Law-systems.

For Fichte, free international trade is not only a living anachronism, but also a situation of anarchy in the international relations that must be solved in order to guarantee peace. ${ }^{72}$ Contrary to Kant, for whom free international trade is the best antidote, even better than cosmopolitan law, against human propensity to war; Fichte thinks of the relation between war and free international trade precisely in opposite terms: free trade economy is not a sublimation or more civilized form of the unsocial sociability present in war, but the very cause of war. Free international trade, Fichte affirms paraphrasing Hobbes, provokes "an endless commercial war of all against all." 73 Whereas in the Kantian account free international trade makes any declaration of war almost impossible, because of the complex chains of interdependence it creates, for Fichte free market stimulates war, because it is the source of poverty, unhappiness, misery and domestic and international political crisis. ${ }^{74}$

Against the anarchy of international trade, which, according to Fichte, is essentially a latent threat for the historical progress of humanity toward perpetual peace, Fichte proposes the dissolution of international trade, which basically consists, as everyone knows, of state's economic isolation. Fichte's closing of the commercial state is, therefore, more than a political issue, since what his theory wants to cancel is not merely an economic system, but rather a moral issue: the egoism of man. Hence, Fichte's political economic program presupposes a cultural revolution based on radical changes of customs, habits and even of taste. His protectionist proposal demands that individuals have to learn a new way of enjoying and having pleasure as well. ${ }^{75}$ The fundamental idea of his protectionist program is not

72. GHS, GA I/7, 92 and 95.

73. GHS, GA I/7, 98.

74. GHS, GA I/7, 99, 106-107, 110-111.

75. GHS, GA I/7, 116. 
only that human progress implies the total extirpation of unsocial sociability from earth, ${ }^{76}$ but first and foremost that social unsociability can and must be extirpated from human nature. According to Fichte, social unsociability is not the real motor of human progress.

At the end of both his Review on Kant's Perpetual Peace and The Closed Commercial State, Fichte suggests that perpetual peace is not only more than "a pious wish," 77 but also than a mere regulative idea, since he does not situate the economic and political realization that this idea demands in an impossible future, but in a far but still possible future. ${ }^{78}$ According to Fichte, a situation of perpetual peace can be achieved, as soon as all nations establish a rule of law and an economic system that according to rational principles guarantee social, political and economic justice and equality, in other words: as soon as the protectionism that Fichte proposes, becomes global. At the end of his 1800 political economy treatise, Fichte describes this globalization process as a kind of domino effect or positive contagious effect: firstly, this political and economic system is established in one country; then, its success attracts the attention and interest of other countries that follow the example; in doing so, Fichte's protectionism extends little by little all over the world until this system becomes the universal rule and perpetual peace becomes a reality. ${ }^{79}$

According to Fichte, the global community that represents the ideal of perpetual peace is not structured by political and economic interdependence connections, but, on the contrary, it consists of a totality composed by isolated parts. The effective reality of the cosmopolitan ideal of perpetual peace reveals itself as the reverse of the usual notion of cosmopolitanism. Moreover, Fichte suggests that the implementation of his protectionism, which is essential for achieving perpetual peace, results in the reinforcement of patriotic love. ${ }^{80}$

The only communication bridges among the states that Fichte allows concerns scientific and artistic cooperation. In doing so,

76. GHS, GA I/7, 118.

77. RezPP, GA I/3, 221.

78. RezPP, GA I/3, 228 and GHS, GA I/7, 141.

79. GHS, GA I/7, 139 and 141.

80. GHS, GA I/7, 139. 
Fichte remains faithful not only to his conviction that real cosmopolitanism is only achieved in the global community that spiritually gathers all rational beings, because true intersubjectivity consists exclusively of knowledge exchange, ${ }^{81}$ but also to his nature-neglecting maxim that "there is no world other than the moral world." 82

\section{SOME REMARKS AS A CONCLUSION}

The offered comparative analysis shows that Kant and Fichte's divergence in conceiving nature in relation to perpetual peace and human progress is at the basis of all the differences between Kant and Fichte's notions of perpetual peace and related concepts such as cosmopolitanism, global justice and equality, war and international trade. Unlike Kant, who develops a special concept of nature for his cosmopolitan philosophy of history-i.e. nature as providence-, Fichte's cosmopolitanism applies the same concept of nature of his Science of Knowledge.

Like Kant, Fichte considers perpetual peace as both the last goal of international politics and the regulative idea for establishing a rational constitution in a nation-state. Nevertheless, Fichte's version of perpetual peace differs from Kant's proposal in the realization. According to Fichte, perpetual peace can only be achieved by a radical protectionism that implies the cancellation of almost all kinds of international relations. As already shown, Fichte seems to have no confidence in the cunning of nature nor in the spirit of trade and the power of money, the efficiency of which in relation to perpetual peace Kant thought to have discovered. Fichte's proposal for a political praxis towards perpetual peace reveals itself as an antinatural move: neutralization or sublimation of desire.

Perpetual peace appears in Fichte's account as the necessary consequence of the universalization of his protectionist political economical proposal. We can reconstruct Fichte's argument as it

81. See, for instance, GA I/2, 89 (On the Dignity of Man, 1794), GA I/3, 41 (On the Destination of the Scholar, 1794) and GA I/3, 348 (Fundations of Natural Law, 1796/97).

82. GA II/12, 118 (Die Tatsachen des Bewusstseyns, 1810/11). 
follows: the only way for making war impossible consists of making economic competition among nation-states impossible, since war is originated by economic interests. On the contrary, Kant's hope that humanity is progressing toward perpetual peace rests in the statement that international trade makes war impossible.

The Kantian "spirit of trade" appears within the Fichtean conception of human progress as one of the forms of the mentioned "obsession for robbery". This egoistic inclination that Kant considers the most beneficial for peaceful international order, is what, in the Fichtean account, has to be attacked. According to Fichte, humanity has to produce a new social and economic order, that makes uninteresting or superfluous the idea of world economic hegemony. Contrary to Kant, whose proposal mainly rests upon the acceptation of the impossibility of cancelling human social unsociability, Fichte thinks that human antagonism is accidental and can therefore be extirpated from earth. This is the reason why Fichte claims that a moral cosmopolitan consciousness is needed for the transformation of the world, whereas morality and human knowledge or wisdom do not play any determinant role in Kant's cosmopolitan view on human historical progress.

Last but not least, both accounts on perpetual peace offers two different forms of understanding global community as a totality. Kant connects the third category of each group of his table of the pure concepts of the understanding: totality, limitation, community as reciprocal effect and necessity. ${ }^{83}$ His notion of global community consists of a complex network of political and economic interdependence that necessarily results from ceaseless reciprocal limitation of freedom. Fichte's perpetual peace, for his part, offers a totality that must renounce to the moment of the relation category, since only the isolation of the parts can constitute the whole that a peaceful global community represents in his account.

83. KrV B 106. 


\section{REFERENCES}

E. Acosta, G. VAn DE VIjver, While reading Kant's Perpetual Peace, in D. Praet (ed.), Philosophy of War and Peace (VUBPress, Brussel, 2017) 131-144.

G. Cavallar, Cosmopolitanisms in Kant's philosophy, "Ethics \& Global Politics" 5/2 (2012) 95-118.

J. G. Fichte, Gesamtausgabe der Bayerischen Akademie der Wissenschaften. E. FuCHS, R. LAuTH, H. JaCOBS, H. GLIWITZKY (eds.), (Frommann-Holzboog, Stuttgart-Bad Cannstatt, 1964-2012).

I. KANT, Gesammelte Schriften, vols. 1-22 ed. by the Preussische Akademie der Wissenschaften, vol. 23 ed. by the Deutsche Akademie der Wissenschaften zu Berlin, vol. 24ff. ed. by the Akademie der Wissenschaften zu Göttingen (DeGruyter, Berlin, 1900ff.).

I. KANT, Idea for a Universal History with the Cosmopolitan Aim, transl. by A. Wood, in A. Oksenberg Rorty, J. Schmidt (eds.), Kant's Idea for a Universal History with a Cosmopolitan Aim. A Critical Guide (Cambridge University Press, Cambridge, 2009) 9-23.

I. Kant, Toward Perpetual Peace: A Philosophical Sketch, transl. by D. Colclausure, in P. KLEINGELD (ed.), Toward Perpetual Peace and Other Writings on Politics, Peace and History (Yale University Press, New Heaven/London, 2006) 67-109.

P. KleIngeld, Kant's Changing Cosmopolitanism, in A. OKsenberG RORTY, J. SCHMIDT, J. (eds.), Kant's Idea for a Universal History with a Cosmopolitan Aim. A Critical Guide (Cambridge University Press, Cambridge, 2009) 171-186.

I. NakHIMOvsky, The Closed Commercial State (Princeton University Press, Princeton, 2011).

H. Traub, Fichtes Begriff der Natur. Rezeptiongeschichte im Wandel Ein Forschungsbericht, in H. GIRNDT (ed.), "Natur" in der Transzendentalphilosophie. Eine Tagung zum Gedenken an Reinhard Lauth (Duncker \& Humblot, Berlin, 2015) 77-134.

L. YPI, Natura Daedala Rerum? On the Fustification of Historical Progress in Kant's Guarantee of Perpetual Peace, "Kantian Review" 14/2 (2010) 118-148. 
